Page 593-601. ISBN: 978-602-6 988-75-1

Web Jurnal Online: jurnal.unmuhjember.ac.id

By: Yusi Eka Rahma Putri Andarini; Itok Wicaksono; Kahar Haerah

Village Efforts In Empowerment of Village Business Entities In Glingseran Village,

Wringin Sub-District, Bondowoso District

\title{
VILLAGE EFFORTS IN EMPOWERMENT OF VILLAGE BUSINESS ENTITIES IN GLINGSERAN VILLAGE, WRINGIN SUB-DISTRICT, BONDOWOSO DISTRICT
}

\author{
Yusi Eka Rahma Putri Andarini; Itok Wicaksono; Kahar Haerah \\ Universitas Muhammadiyah Jember \\ Email: itokwic4ksono@gmail.com \\ Emai ; kaharhaerah@unmuhjember.ac.id
}

\begin{abstract}
Village Ministerial Regulation No. 3 of 2015 mandates the Village Assistant to assist the Village Government in order for the Village Government to run according to the regulations, namely transparent and accountable. One of the Village Assistant's demands is to build and develop a Village Owned Enterprise which is one of the four pillars of village development priority. The village government of Glingseran is a village that owns a village owned enterprise. Therefore, it is expected that the Village Assistant should make efforts to make the Village Owned Enterprise able to support the economy of the village community and increase the village's original income (PAD). In this research, the researcher tries to examine the efforts of the village assistant in the empowerment of the village-owned enterprise in Glingseran village, Wringin sub-district, Bondowoso regency. The method used in this research is qualitative with descriptive approach. The result of the research found by the researcher is the efforts of the village counselor and the local village facilitator in the empowerment is good enough to be seen from the tasks that have been implemented by the village counselor to empower the village owned business enterprise successfully that is with the increase of business unit business unit into 3 business units that is rengganis tourist village, party equipment rental and savings and loan women. And the village facilitators perform their duties in accordance with the Standard Operational Procedures established by the Ministry of Village, Development of Disadvantaged Regions and Transmigration of the Republic of Indonesia as well as the opening of employment opportunities, and the increase of the village's original income (PAD) Glingseran.
\end{abstract}

Keywords: Effort, Assistant, Bumdes 
Page 593-601. ISBN: 978-602-6 988-75-1

Web Jurnal Online: jurnal.unmuhjember.ac.id By: Yusi Eka Rahma Putri Andarini; Itok Wicaksono; Kahar Haerah Village Efforts In Empowerment of Village Business Entities In Glingseran Village, Wringin Sub-District, Bondowoso District

\section{INTRODUCTION}

The Central Government currently gives authority to the Village Government to regulate its own households. This requires the village to be independent, one of which is in improving the village economy. in this case the government made a village law governing all village activities. one of them is an article regulating that every village in Indonesia build a Village-Owned Enterprise (BUM Desa). one of the villages that has BUM Desa is Glingseran Village. However, BUM Desa has not had significant development after it was built in 2015. As if the AD-ART and Village Regulation or Village Head's Decree governing Village BUMs have not yet been formed so that they cannot spend the night as they should. In addition, to assist the Village Government in developing villages, the Government issued Village Minister Regulation No. 3 of 2015 concerning Village Assistance. Village assistance is carried out by village facilitators. village assistants are tasked with assisting villages in village development from the beginning of development planning to the end.

Seeing the problems in Glingseran Village and BUM Desa, it is also one of the 4 main pillars of village development that must be encouraged by village assistants so that the 4 pillars are realized. Therefore, how the efforts of village assistants in empowering village-owned enterprises in Glingseran Village, Wringin Sub-District, Bondowoso Regency.

\section{LITERATURE REVIEW}

\section{A. Efforts to assist the village in empowering village-owned enterprises}

Efforts according to the big Indonesian dictionary (KBBI) are defined as business activities that direct energy, thoughts to achieve a goal. Efforts also mean effort, reason, endeavor to achieve a purpose, solve problems looking for a way out. Village Facilitator is someone who performs the task of assisting villages, namely carrying out community empowerment actions through assistance, organizing, directing and facilitating the Village. Village Facilitators here there are 2 types of facilitators namely Empowerment Village Assistance (PDP) and Infrastructure Technical Village Assistance (PD-TI) who work in the sub-district and are responsible for all villages in the sub-district. In addition to Village Facilitators, there are also those who have special duties in the village, namely the village's local companion. Local village facilitators have the duty and responsibility to assist the village where they are assigned. Usually the local village assistant is responsible for one or more villages and a maximum of local village facilitators is responsible for assisting 4 villages. The focus of this research is the Effort of Empowering Village Empowerment (PDP) and Village Local Assistance. The efforts of village facilitators and village local assistants can be understood as an activity or activities carried out by village facilitators to achieve their goal of empowering, the empowerment meant here is the empowerment of village-owned enterprises. 
Page 593-601. ISBN: 978-602-6 988-75-1

Web Jurnal Online: jurnal.unmuhjember.ac.id By: Yusi Eka Rahma Putri Andarini; Itok Wicaksono; Kahar Haerah Village Efforts In Empowerment of Village Business Entities In Glingseran Village, Wringin Sub-District, Bondowoso District

\section{B. Empowerment of Village-Owned Enterprises (BUM Desa)}

With regard to the meaning of the concept of community empowerment, Winarni revealed that the core of empowerment is to include three things namely development, (enabling), strengthening the potential or power (empowering), the creation of independence (Tri Winarni, 1998: 75). In accordance with this theory, empowerment is an effort to provide power or increase power, empowerment of village-owned enterprises is an effort to provide power or increase the power of Village-Owned Enterprises.

Village-Owned Enterprises, hereinafter referred to as BUM Desa, are business entities whose entire or most of their capital is owned by the Village through direct participation from village assets that are separated to manage assets, services, and other businesses for the maximum welfare of the community. Establishment of BUMDes is intended as an effort to accommodate all activities in the economic field and / or public services managed by the Village and / or inter-Village cooperation.

BUM Desa can run a renting business, brokering business, and financial business. Establishment of village-owned business entities agreed upon through village deliberations.

The initial capital of BUM Desa is sourced from the Village APB consisting of Village capital participation and Village community capital participation. Village capital investment consists of:

a. Grants from the private sector, social and economic institutions and/or donor agencies distributed through the Village APB mechanism;

b. Assistance from the Government, Provincial Governments and Regency/City Governments distributed through the Village APB mechanism;

c. Business cooperation from the private sector, social and economic institutions and/or donor agencies that are ensured as village collective wealth and channeled through the Village APB mechanism.

d. Village Assets submitted to the Village APB are in accordance with statutory provisions concerning Village Assets

\section{RESEARCH METHOD}

In this study the authors used a type of qualitative research. The method used as a reference in this study is descriptive. Descriptive method is a study to find facts with the correct interpretation accurately describing the nature of some phenomena, groups or individuals, determining the frequency of occurrence of a situation.

This research was conducted in Glingseran Village, Wringin District, Bondowoso Regency.

Data collection methods in this study using the method of observation, interviews and documentation.

This research uses Miles and Huberman's (2007:20) theory of data analysis method through three stages:

1. Redux data

2. Display data

3. Conclusions and verification 
Page 593-601. ISBN: 978-602-6 988-75-1

Web Jurnal Online: jurnal.unmuhjember.ac.id By: Yusi Eka Rahma Putri Andarini; Itok Wicaksono; Kahar Haerah Village Efforts In Empowerment of Village Business Entities In Glingseran Village, Wringin Sub-District, Bondowoso District

\section{DISCUSSION}

Bondowoso Regency, is a regency in East Java Province, Indonesia. The capital city is Bondowoso. The capital of the regency of Bondowoso is at the crossing of the lane from Besuki and Situbondo to Jember. Bondowoso Regency is a regency that does not have a sea area (landlocked) and is located in the horseshoe area, East Java.

Bondowoso Regency can be divided into three regions: The western region is a mountain range (part of the Iyang Mountains), the central part is a plateau and is bumpy, while the eastern part is a mountain range (part of the Ijen Plateau). Bondowoso is the only district in the horseshoe area that does not have a coastline.

Bondowoso Regency is one of the regencies in East Java Province located east of Java Island. Known as the horseshoe area. The capital is Bondowoso. Bondowoso Regency has an area of $1,560.10 \mathrm{~km} 2$ which is geographically located at coordinates between $113^{\circ} 48^{\prime} 10^{\prime \prime}-113^{\circ} 48^{\prime} 26^{\prime \prime}$ East and $7^{\circ} 50^{\prime} 10^{\prime \prime}-7^{\circ} 56^{\prime} 41$ " LS.

Meanwhile, Glingseran Village is a village located in Wringin sub-district, Bondowoso Regency with a distance of 16 kilometers from the city and 2 kilometers from the sub-district and has a height of 400 meters from the sea surface. Following are the general conditions of Glingseran Village

North side: Banyuputih Village

Southern Side: Ambulu Village

West side: Tamansari Village

East side: Tamansari Village

Glingseran Village has an area of 2,539,106 Ha which is divided into several sections.

\section{A. Village Facilitating Efforts in Empowering Village-Owned Enterprises in Glingseran Village, Wringin District, Bondowoso Regency}

According to the big Indonesian dictionary, effort is an effort, endeavor or way to achieve a goal. In this study, researchers tried to see the efforts of village assistants in empowering village-owned enterprises. The effort carried out by the village facilitator in empowering the village-owned enterprises of Karya Sejati is to carry out the tasks as planned and in accordance with the rules set in the operational standards for professional development and control of professionals.

\section{B. Village Assistance Duties in Empowering Village-Owned Enterprises in Glingseran Village, Wringin District, Bondowoso Regency}

Based on the Regulation of the Minister of Villages, Development of Disadvantaged Areas and Transmigration of the Republic of Indonesia Number 3 of 2015 concerning Village Assistance and standard operating procedures for the guidance and control of professionals, Village Assistance tasks include:

a. Assisting the Village in planning, implementing, and monitoring village development.

b. Assist the Village in participatory rural development.

c. Coordinating assistance at the sub-district level and facilitating implementation reports and facilitating the implementation of assistance by the camat to the district government. 
d. Accompanying the village in carrying out village economic development.

Based on standard operating procedures for guidance and control of professional staff, village assistants have 2 tasks, namely the main task and administrative tasks and one of the assistant tasks for BUMDesa Development, and the following is a description of the tasks of the village assistant including:

1) Main Task of Village Companion

a. Accompanying the subdistrict government in the implementation of the Village Law No. 6 of 2014 concerning Villages.

b. Village Deliberation Facilitation.

c. Facilitation of compilation of village / inter-village legal products

d. Assist and control Village Local Assistance in carrying out the main tasks and functions.

e. Facilitation of collaboration between villages with third parties.

f. Assist the Village in planning, implementing, monitoring development and community empowerment in the Village.

2) Administrative Assistance of Village Assistance

a. Submit monthly reports to the sub-district head and the P3MD (Development and Empowerment Program) work unit.

C. The Task of Village Local Assistance in Empowering Village-Owned Enterprises in Glingseran Village, Wringin District, Bondowoso Regency

The Task of Village Local Assistance in the Standard Operational Procedures for Professional Development and Control

a. Accompanying the Village in the development planning and realization of Village finances.

b. Assist the Village in the implementation of Village development.

c. Assisting the Village in monitoring and evaluating Village development activities.

d. Delivering monthly reports to Village Facilitators and P3MD work units (Village Community Empowerment and Development Program).

D. Purpose of Village Assistance in Empowering Village-Owned Enterprises in Glingseran Village, Wringin District, Bondowoso Regency

1. Increase the capacity, effectiveness and accountability of the Village Government and village development. Village Facilitators in increasing the capacity, effectiveness and accountability of village governments and Village development, Village facilitators and Village local assistants carry out their main tasks and functions well, one of which is the development of Village-owned Enterprises. so that the development and development of village-owned business entities in Glingseran Village are carried out properly there are objectives or processes that must be carried out by the village government and village assistants along with local village assistants, namely:

a. Carry out socialization on Village Law number 6 in 2014.

b. Implementation of Village Development Planning Deliberation (Musrenbang Desa). 
c. Facilitating Review and evaluation of Village RPJM documents, Village RKP, Village APB, and Accountability Reports.

d. Facilitation of Village Law products.

e. Good coordination between village facilitators, local village assistants and the village government of Glingseran.

2. Increasing community initiative, awareness and participation in village development that is participatory

3. Optimizing village local assets in an emancipatory manner.

\section{E. Factors Affecting the Village Facilitator's Efforts in Empowering Village-Owned Enterprises in Glingseran Village, Wringin District, Bondowoso Regency}

There are two kinds of factors that influence the companion's efforts in empowering, namely supporting factors and inhibiting factors. The following are the supporting and inhibiting factors of the village escort's efforts in implementing the empowerment of village-owned enterprises.

\section{Supporting Factors of Village Facilitating Efforts in Empowering Owned Enterprises in Glingseran Village, Wringin District, Bondowoso Regency}

The supporting factors of the efforts of the Village Facilitator and the Village Local Facilitator are in providing assistance:

a. quality and ability of employees that is related to education and training.

b. Supporting facilities such as technology, special office assistant located in Wringin District. In addition, the companion gets a guide book in the form of a module as a guide in carrying out the task. Then other supporting facilities are about the welfare of the companion in the form of wages / salaries.

c. Supra facilities such as policies or regulations such as ministerial regulation number 3 of 2015 concerning village assistance and industrial management such as standard operating procedures (SOP).

2. The Inhibiting Factor of Village Facilitating Efforts in Empowering VillageOwned Enterprises in Glingseran Village, Wringin District, Bondowoso Regency

In addition to supporting factors, of course there are factors that hamper the efforts of Village Facilitators and Village Local Assistance. based on data in the field. The following are obstacles to the efforts of village facilitators in empowering villageowned enterprises in Glingseran village:

a. Communities that are less open to empowerment.

b. The village government sometimes does not immediately carry out what was planned.

c. The village government is bound by promises to the people which ultimately overrides empowerment.

d. Regulation that limits village facilitators and local village assistants in making decisions 
Page 593-601. ISBN: 978-602-6 988-75-1

Web Jurnal Online: jurnal.unmuhjember.ac.id By: Yusi Eka Rahma Putri Andarini; Itok Wicaksono; Kahar Haerah Village Efforts In Empowerment of Village Business Entities In Glingseran Village, Wringin Sub-District, Bondowoso District

\section{F. CONCLUSION}

Based on the research carried out, the efforts made by the Village Facilitators and Village Local Assistance are already good. It can be seen from the implementation of the tasks carried out by the village facilitators and local village assistants, namely:

1) Main Task of Village Companion

a. Accompanying the subdistrict government in the implementation of the Village Law No. 6 of 2014 concerning Villages.

b. Village Deliberation Facilitation.

c. Facilitation of compilation of village / inter-village legal products

d. Assist and control Village Local Assistance in carrying out the main tasks and functions.

e. Facilitation of collaboration between villages with third parties.

f. Assist the Village in planning, implementing, monitoring development and community empowerment in the Village.

2) Administrative Assistance of Village Assistance

a. Submit monthly reports to the sub-district head and the P3MD (Development and Empowerment Program) work unit.

3) Assist the Village in the development planning and realization of the Village finances.

a. Accompanying the Village in the implementation of Village development.

b. Assisting the Village in monitoring and evaluating Village development activities.

c. Delivering monthly reports to Village Facilitators and P3MD work units (Village Community Empowerment and Development Program).

In addition to the tasks that have been carried out, the purpose of assistance has also been achieved. Includes:

1. Increase the capacity, effectiveness and accountability of the Village Government. In increasing the capacity, effectiveness and accountability of the Village Government. Village Facilitators encourage the village government to:

a. Carry out socialization on village law number 6 in 2014.

b. Carry out deliberations on village development plans (musrenbang).

c. Facilitating the review and evaluation of Village RPJM documents, Village RKP, Village APB, and accountability reports.

d. Facilitation of village legal products.

e. Good coordination between village facilitators, village local assistants, and the government of Glingseran Village.

2. Increasing community initiatives, awareness and participation in village development that is participatory.

3. Optimizing village local assets.

4. Opening jobs through BUM Desa.

5. Increase the income of the village community and the village's original income.

6. Improve the village economy.

7. Develop a business cooperation plan between villages and / or third parties. 
Page 593-601. ISBN: 978-602-6 988-75-1

Web Jurnal Online: jurnal.unmuhjember.ac.id By: Yusi Eka Rahma Putri Andarini; Itok Wicaksono; Kahar Haerah Village Efforts In Empowerment of Village Business Entities In Glingseran Village, Wringin Sub-District, Bondowoso District

In village assistance, there are factors that inhibit and support village assistance. The supporting factors for village assistance include:

1. Quality and ability of professional escorts

In supporting the quality and ability of professional assistants, the village ministry provides training to professional assistants before serving. Then the village facilitators received training from the work unit of the village community development and empowerment program (P3MD) and training from the Inspectorate and KOMPAK.

2. Supporting Facilities

Supporting facilities for professional assistants are village assistant offices as well as computer technology and supporting facilities for the welfare of assistants, namely salaries.

3. Supra means

Supra facility is the regulation of the Minister of the Village Number 3 of 2015 concerning Village Assistance. because if there is no Ministerial regulation, there will be no village assistance. The Ministerial Regulation is one of the main factors in the implementation of village Facilitation.

In addition to supporting factors, there are factors that hamper the efforts of village facilitators in the efforts to empower village-owned enterprises in Glingseran Village, namely:

1. Society is less open to empowerment.

2. 2. Empowerment is not a priority.

3. Regulations that limit village assistants and local village assistants in making decisions.

4. Local village facilitators who are responsible for more than one village.

\section{G. Suggestions}

The suggestions that can be proposed by the authors as a result of this research in the framework of village assistance include:

1. It is better for village facilitators to focus on just one village so that efforts in empowering village-owned business entities are more leverage.

2. Village facilitators and local village assistants should socialize more often with the community so that the community is more open with empowerment and more aware of the importance of empowerment. 
Page 593-601. ISBN: 978-602-6 988-75-1

Web Jurnal Online: jurnal.unmuhjember.ac.id By: Yusi Eka Rahma Putri Andarini; Itok Wicaksono; Kahar Haerah Village Efforts In Empowerment of Village Business Entities In Glingseran Village, Wringin Sub-District, Bondowoso District

\section{REFERENCES}

Sugiyono. Metodologi Penelitian Pendidikan Pendekatan Kuantitatif, Kualitatif dan $R \& D$. Alfabeta : Bandung. 2016.

Prajoko Ludiro, et al. Modul Pelatihan Pratugas Pendamping Lokal Desa Pendampingan Desa. Kementrian Desa, Pembangunan Daerah Tertinggal, dan Transmigrasi Republik Indonesia: Jakarta. 2016.

Kementrian Desa, Pembangunan Daerah Tertinggal, dan Transmigrasi Republik Indonesia. Modul Pelatihan Pratugas Pendamping Desa Pemberdayaan. Kementrian Desa, Pembangunan Daerah Tertinggal, dan Transmigrasi Republik Indonesia : Jakarta. 2016.

Sumpeno Wahjudin, et al. Modul Pelatihan Pratugas Pendamping Desa (Kompetensi Umum). Kementrian Desa, Pembangunan Daerah Tertinggal, dan Transmigrasi Republik Indonesia : Jakarta Selatan. 2016.

Direktorat Jenderal Pembangunan dan Pemberdayaan Masyarakat dan Desa, Kementrian Desa, Pembangunan Daerah Tertinggal dan Transmigrasi Repubik Indonesia. Standar Operasional dan Prosedur Pembinaan dan Pengendalian Tenaga Pendamping Desa. Jakarta. 2016.

Peraturan Menteri Desa, Pembangunan Daerah Tertinggal dan Transmigrasi Republik Indonesia Nomor 3 Tahun 2015 Tentang Pendamping Desa.

Peraturan Menteri Desa, Pembangunan Daerah Tertinggal dan Transmigrasi Transmigrasi Republik Indonesia Nomor 4 Tahun 2015 Tentang Pendirian, Pengurusan, Pengelolaan, Dan Pembubaran Badan Usaha Milik Desa.

Peraturan Pemerintah Republik Indonesia Nomor 43 Tahun 2014 Tentang Peraturan Pelaksanaan Undang-undang Nomor 6 Tahun 2014.

Peraturan Menteri Desa, Pembangunan Daerah Tertinggal dan Transmigrasi Transmigrasi Republik Indonesia Nomor 19 Tahun 2017 Tentang Penetapan Prioritas Penggunaan Dana Desa Tahun 2018. 